\title{
Assessing Rainfall Variability at Adwa District, Central Tigray, Ethiopia
}

\author{
Mekonnen Yibrah $^{1 *}$, TilahunDandesa ${ }^{2}$, Bekele Kebebe $^{3}$, Bezuneh Sego ${ }^{4}$ \\ ${ }^{1}$ Tigray Meteorology Service Center, Mekelle, Ethiopia \\ ${ }^{2}$ Agricultural Transformations Agency, Addis-Ababa, Ethiopia \\ ${ }^{3}$ National meteorology Agency, Addis-Ababa, Ethiopia
}

*Corresponding Author: Mekonnen Yibrah, Tigray Meteorology Service Center, Mekelle, Ethiopia

\begin{abstract}
Rainfall is the most important but variable climatic element in semi-arid regions. The present study assessed rainfall variability at Adwa District, central Tigray, Ethiopia. The assessed gridded climate data revealed that the long-term annual rainfall showed high variability from year to year with $22.9 \%$ coefficient of variation. Seasonally, the MAM total rainfall showed higher variability than the JJAS total rainfall amount. Hence, indicated that (seasonally) ONDJF, JJAS, MAM, and the annual total rainfall amount had been failing increasingly in the study area with $89.7 \%, 24.7 \%, 62.7 \%$ and $22.9 \%$ respectively.

Except onset date, cessation date and length of growing season were highly variable. The main/JJAS season curves of dry spell probability at different lengths Dry spell length converges to their minimum during months of peak rainfall periodsfrom180DOY-250DOY (28June-06Sep) and diverges again from 250DOY--265DOY (06Sept-21Sep)signaling end of the growing season. This suggests that standing crops after this time will face increasingly greater risk of water shortages in the study area. Except ONDJF with insignificant increasing trend, the annual, MAM, JJAS and MAM rainfall amount was decreasing significantly. The Probability of occurrence of dry spell length during the main season/JJAS in association with significant decreasing trend in rainfall amount in the main season/JJAS had a negative impact on the agricultural activities of the study area during the study period (1983-2013).
\end{abstract}

Keywords: Rainfall, Variability, Trend, Adwa.

\section{INTRODUCTION}

Climate variability and change are affecting the whole world (IPCC, 2007). The impacts are significantly negative on rain fed agriculture (Travis et al., 2010) on which the economies of most developing countries depend (Lamboll et al., 2011) with less adaptive capacity (Michael, 2006; Yesuf et al., 2008; UN-OHRLLS, 2009). Particularly, many low income countries, located in the tropical and sub-tropical region are vulnerable to shifting and variable climate (Joachim, 2008).

Agriculture plays a dominant role in the economy of Ethiopia, contributing $41 \%$ GDP, $80 \%$ of the employment and the majority of foreign exchange earnings (Gebreegziabher et al., 2011). The success of agricultural production has, therefore, large implications, ranging from the state of the countrywide economy to the survival of the subsistence farmers (Block and Rajagopalan, 2007). Natural rainfall is the main source of water for crop production as irrigation covers only $5 \%$ of the cultivated land in the country (Awulachew et al., 2010). Several studies (Hagos et al., 2009; Osman and Sauerborn, 2002) examined the impact of rainfall variability on the Ethiopian economy, and found that rainfall variability in the country led to a production deficit (20\%) and increase in poverty rates (25\%) which coasted the economy over one-third of its Growth potential. Therefore, the objective of this study is to assess Rainfall variability, trend, onset date, cessation date and length of growing season in the study area and the nearby's. 


\section{MATERIALS AND MethodS}

\subsection{Description of the Study Area}

The study area is located in the Tigray National Regional State of the Federal Democratic Republic of Ethiopia. Geographically, it is located at $14.17^{\circ} \mathrm{N}$ Latitude and $38.88^{\circ}$ E Longitude with elevation $1927 \mathrm{mt}$, bordered on the south by Werie Leke, on the west by Lailay Maychew, on the north by Mereb-Leke, and on the east by Enticho. The prevailing climate in Adwa is known as a local steppe climate. The climate here is classified as BSh by the Köppen-Geiger system.

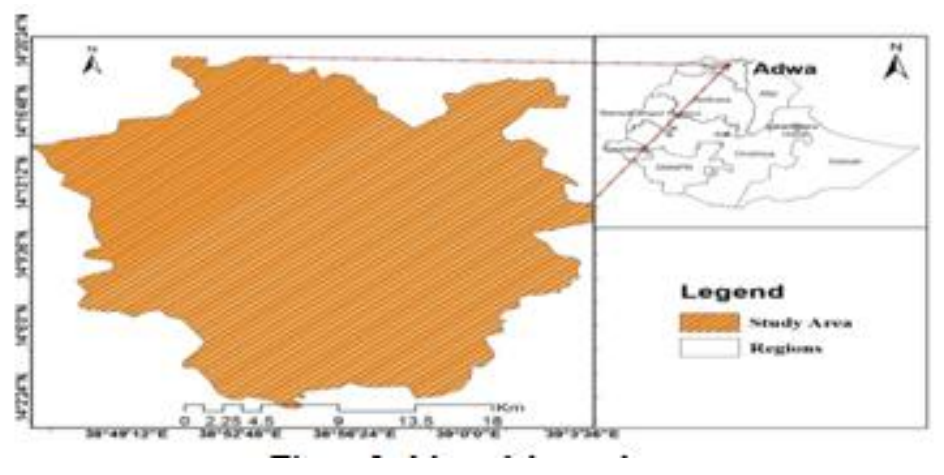

Figure1. Map of the study area

\subsubsection{Data Source and Station Selection}

Long-term gridded daily rainfall data (1983-2013) of the study area located in the central Tigray region of Ethiopia was collected from the National Oceanic and Atmospheric Administration (NOAA).

\subsection{Rainfall Variability Analysis}

Thirty years of observed rainfall data was used to assess seasonal and annual rainfall variability. The long-term total rainfall amount and temporal range during the growing season of the study area was assessed by processing the daily rainfall data using INSTAT Climatic Guide (Stern et al., 2006). In order to determine onset of rainfall in each seasons (JJAS and MAM), the definition of effective onset of rainfall was employed from past rainfall data. In this study, the first occasion after March 1st when rainfall accumulated in three consecutive days is at least $20 \mathrm{~mm}$ and no dry spell of more than 7 days in the next 30 days was used as an actual onset of rainfall. The end of growing season (end date), on the other hand, was defined as the first date after $1^{\text {st }}$ September when the soil water drops to 10 $\mathrm{mm} /$ meter within 10 days after which there is no rainfall for the next 10 days. The onset and end date criteria were used to determine the length of growing season as total number of days from the date of onset of rainfall to the end date of the rainfall. The daily rainfall data was processed to give probabilities of maximum dry spell lengths exceeding 5, 7, 10, 15 and 20 days starting from January first. In a box and whiskers plotting, the box represents the middle $50 \%$ of the whole data set, while whiskers represent the magnitude of the spread of the rest of the data set about the median or mean (Stern et al., 2006).

\section{RESULTS AND DISCUSSION}

\subsection{Dekadal, Monthly, Seasonal and Annual Rainfall Variability}

The amount and distribution of Seasonal and Annual total rainfall are useful information on rainfall variability over an area. The Seasonal (MAM, JJAS, and ONDJF) and annual total rainfall amount of the study area ranged from 23 to $271 \mathrm{~mm}, 489$ to $1432 \mathrm{~mm}, 1$ to $173 \mathrm{~mm}$ and 547 to $1607 \mathrm{~mm}$ respectively. Coefficient of variation is much higher for MAM than JJAS seasonal total rainfall indicating higher temporal variability of the MAM seasonal total rainfall. The annual total rainfall also showed high variability. The JJAS, MAM and ONDJF seasons rainfall contributes $82.4 \%, 12.2 \%$ and $5.3 \%$ of the total annual rainfall respectively (Table 1). 
Table1. Descriptive statistics of annual and seasonal (MAM and JJAS) rainfall total of Adwa for 30 years (1983-2013).

\begin{tabular}{|l|l|c|c|c|}
\hline \multirow{2}{*}{ Descriptive statistics } & \multicolumn{3}{|c|}{ Seasonal rainfall total } \\
\cline { 2 - 5 } & $\begin{array}{l}\text { Annual } \\
\text { rainfall } \\
\text { total (mm) }\end{array}$ & JJAS (mm) & MAM (mm) & $\begin{array}{c}\text { Rest months } \\
\text { (ONDJF) }\end{array}$ \\
\hline Maximum & 1607 & 1432 & 271 & 173 \\
\hline Minimum & 547 & 489 & 23 & 1 \\
\hline Mean & 861.2 & 709.8 & 105.4 & 46.0 \\
\hline C.V & 22.9 & 24.7 & 62.7 & 89.7 \\
\hline SD & 197.7 & 176.3 & 66.0 & 37.6 \\
\hline Proportion (\%) & --- & $82.4 \%$ & $12.2 \%$ & $5.3 \%$ \\
\hline
\end{tabular}

\subsection{Onset, End Date and Length of Growing Season}

Upon the definition set Using INSTAT climate guide a time series analysis of daily rainfall of a specific area from the past record gives a good picture to decide the possible onset date, cessation date and length of growing season. In line with this, the average onset date at the study area from (19832013) was 173/11Jun followed by the early onset date 159DOY/07Jun with the late onset date 188DOY/06Jul. The early offset date was 255DOY/11Sept and the late offset was 288/140ct. Therefore, the average onset date, offset date and length of the rainy season/JJAS was on 173DOY/21Jun, 277DOY/03Oct and 104 days respectively. In line with this, Araya and Stroosnijder (2011) and Hadgu et al. (2013) also reported similar findings (Figure 1).

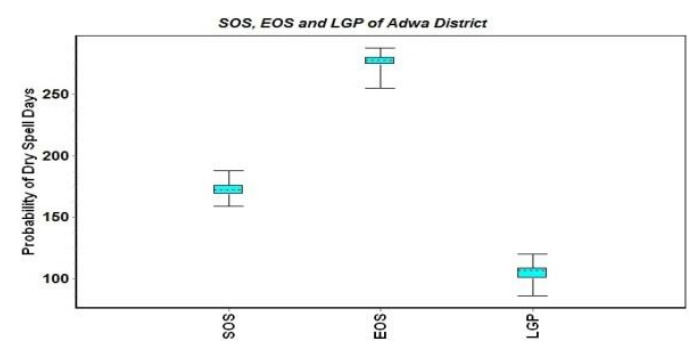

Figure2. Box whisker plots of onset date, end date and length of growing Period for Kiremt Season at Adwa District (1983-2013).

\subsection{Probability of Dry Spell Length}

During the main season/JJAS curves of dry spell probability at different lengths. Dry spell length converges to their minimum during months of peak rainfall periodsfrom180DOY-250DOY (28June06Sep) and diverges again from 250DOY--265DOY (06Sept -21Sep) signaling end of the growing season. This suggests that standing crops after this time will face risk of water shortages in the study area.

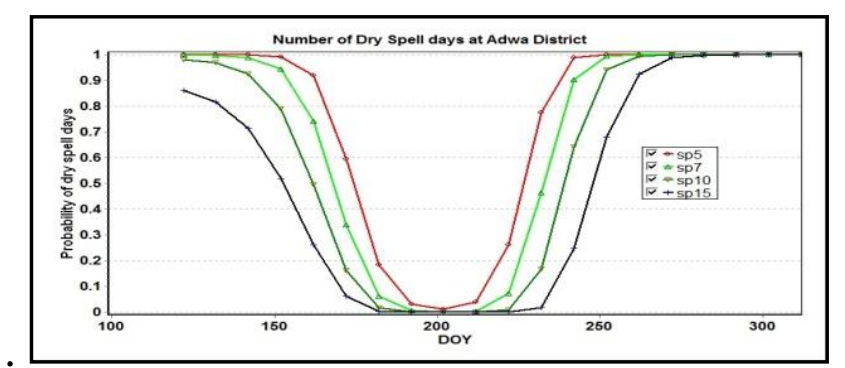

Figure3. Probabilities of maximum dry spells exceeding 5, 7, 10, 15 and 20 day's length at Adwa District, during the period of study (1983-2013).

\subsection{Dekadal, Monthly, Seasonal and Annual Rainfall Trends}

The long-term Dekadal, Monthly and Bega/ONDJF total rainfall showed insignificant increasing trend but the annual and seasonal/ MAM and JJAS/ total rainfall showed significant decreasing trend. Thus, Thus, corresponding with this significant decreasing seasonal rainfall trend, Minimizing the risks of crop failure and ensure food security that can happen due to climate variability is possible by integrating those indigenous and scientific knowledge, such as sowing the crops on the right time and by exercising different climate change adaptation mechanisms. Furthermore, Climate risk analysis and 
weather forecast information is very useful for agricultural planning and production of farmers and decision makers.

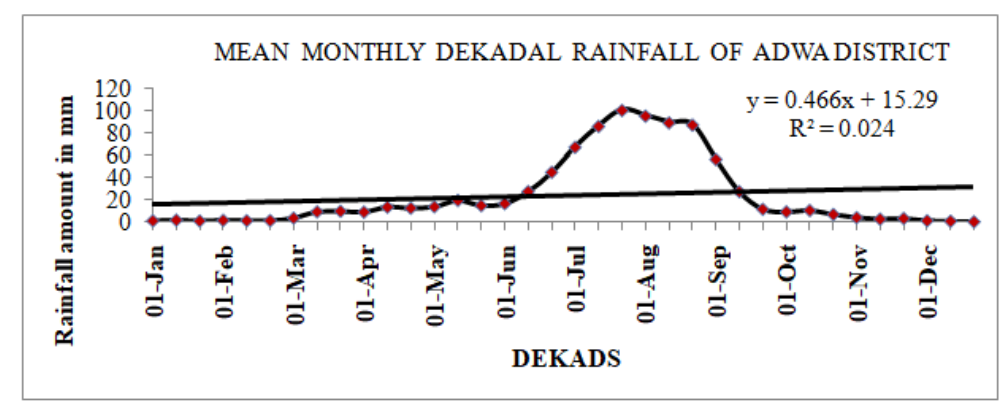

Figure4. Dekadal rainfall variability at Adwa District (1983-2013).

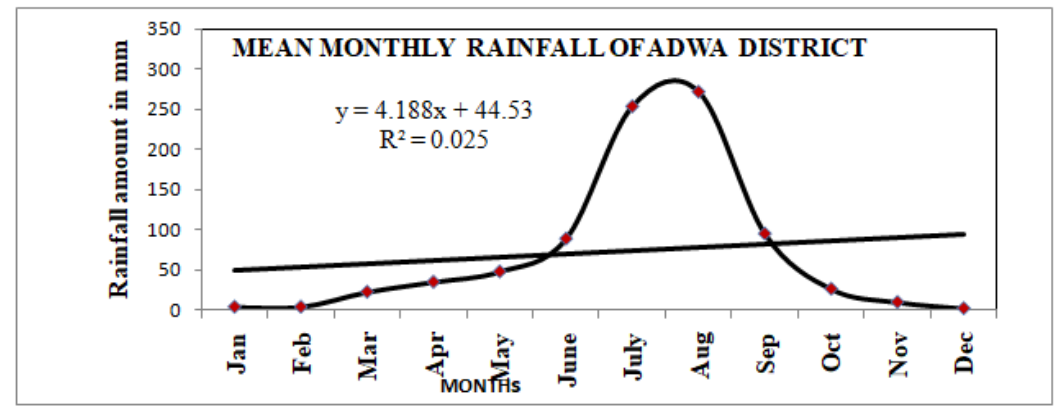

Figure5. Mean monthly rainfall variability in Adwa District (1983-2013).

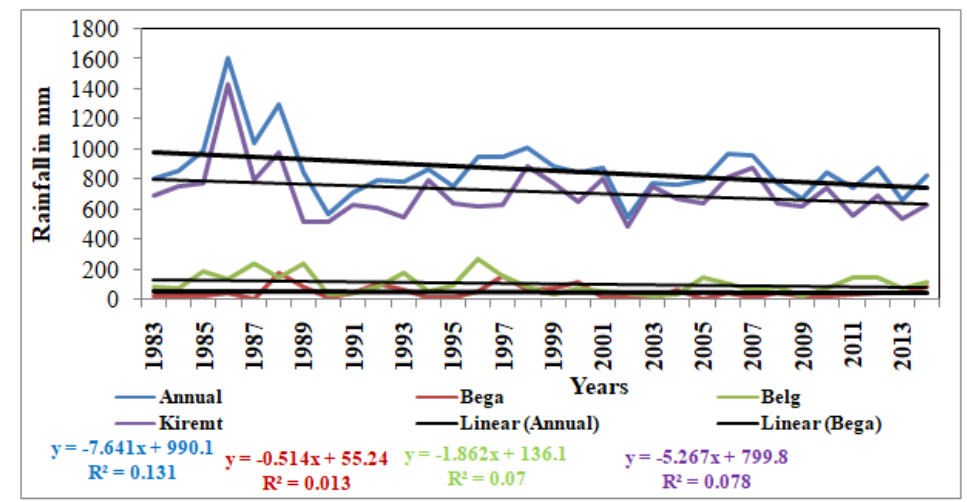

Figure6. Annual and seasonal rainfall trend at Adwa District (1983-2013).

\section{CONClusion}

The result showed that the study area received mean annual and seasonal (JJAS, MAM and ONDJF) rainfall totals $861.2 \mathrm{~mm}, 709.8 \mathrm{~mm}, 105.4 \mathrm{~mm}$ and $46.0 \mathrm{~mm}$ respectively. Annual and seasonal total rainfall $\mathrm{CV}$ has been failing increasingly in the study area with $22.9 \%, 24.7 \%, 62.7 \%$ and $89.7 \%$ respectively. The average SOS, EOS and LGP was 173DOY/21June, 277DOY/03Oct and 104 days respectively. Moreover, Onset date and length of growing season were highly variable. ONDJF rainfall showed insignificant increasing trend but the MAM and the main season/JJAS showed significant rainfall decreasing trend. The main season/JJAS curves of dry spell probability at different lengths Dry spell length converges to their minimum during months of peak rainfall periods from 180DOY-250DOY (28June-06Sep) and diverges again from 250DOY--265DOY (06Sept -21Sep) signaling end of the growing season. This suggests that standing crops after this time will face increasingly greater risk of water shortages in the study area.

\section{RECOMMENDATION}

Corresponding with this significant decreasing seasonal rainfall during the main season/JJAS, minimizing the risks of crop failure and ensure food security that can happen due to climate variability is possible by integrating those indigenous and scientific knowledge, such as sowing the crops on the right time and by exercising different climate change adaptation mechanisms. 
Though the study area is amonomodal climatic District, farmers should use rainfall of MAM for more productivity by sowing short period growing crops and should use seasonal climate outlook for adjusting their farm operations and farming system decisions to avert the risk of rainfall variability.

\section{REFERENCES}

[1] Awulachew SB, Erkossa T, Namara RE (2010). Irrigation potential in Ethiopia: Constraints and opportunities for enhancing the system. Report for IWMI.

[2] Block P, Rajagopalan B (2007). Interannual variability and ensemble forecast of upper Blue Nile basin kiremt season precipitation. Am. Meteorol. Soc. 8:327-343. http://dx.doi.org/10.1175/JHM580.1

[3] Gebreegziabher Z, Stage J, Mekonnen A, Alemu A (2011). Climate change and the Ethiopian economy: A computable general equilibrium analysis. Environment for Development Discussion Paper Series, p. 24.

[4] Hagos F, Makombe G, Namara RE, Awulachew SB (2009). Importance of irrigated agriculture to the Ethiopian economy: Capturing the direct net benefits of irrigation. Colombo, Sri Lanka: Int. Water Manage. Inst. p.37. (IWMI Research Report 128)

[5] IPCC. Climate Change Synthesis Report. Contribution of Working Groups I, II and III to the Fourth Assessment Report of the Intergovernmental Panel on Climate Change [Core Writing Team, Pachauri, R.K and Reisinger, A. (eds.)]. IPCC, Geneva, Switzerland, 2007:104 pp

[6] Joachim, G. 2008. Rural 21 volume 43 the ultra-poor neglected resource, future potential.International Journal for Rural Development. No.5/2008 issue number: 1866-8011.D20506F. hpp//www.rural.21.com. Accessed on September 25, 2014.

[7] Lamboll. R, Valerie, N. and Nick, N. 2011: Emerging approaches for responding to climate change in African agricultural advisory services, Challenges, opportunities and recommendations

[8] Michael C. 2006.World Wide Fund for Nature Climate Change Scientist, Gland, Switzerland.

[9] Osman M, Sauerborn P (2002). A preliminary assessment of characteristics and long-term variability of rainfall in Ethiopia basis for sustainable land use and resources management.Conference on International Agricultural Research for Development, DeutscherTropentag 2002, Witzenhausen, Germany.

[10] Travis, L. and Daniel, S. 2010: Agricultural Technologies for Climate Change Mitigation and Adaptation in Developing Countries: Policy Options for Innovation and Technology Diffusion. International Centre for Trade and Sustainable Development -IPC Platform on Climate Change, Agriculture and Trade. Issue Brief No. 6. 33 p.

[11] UN-OHRLLS 2009.The impact of climate change on the development project of the least developed countries and small island developing states.

[12] Yesuf, M., Salvatore, D.F., Temesgen, D.R., and Gunnar, K. 2008. The impact of climate change and adaptation of food production in low-income countries: Evidence from the Nile Basin, Ethiopia. IFPRI discussion paper 2008. Pp. 1-16.

Citation: M. Yibrah et al., "Assessing Rainfall Variability at Adwa District, Central Tigray, Ethiopia", International Journal of Research in Environmental Science, vol. 4, no. 4, pp. 1-5, 2019. Available: http://dx. doi.org/10.20431/2454-9444.0501001

Copyright: () 2019 Authors. This is an open-access article distributed under the terms of the Creative Commons Attribution License, which permits unrestricted use, distribution, and reproduction in any medium, provided the original author and source are credited. 